\title{
A testimony of detachment of an inland lake from marine influence during the mid-Holocene in the Vestfold Hills region, East Antarctica
}

\author{
Abhijit Mazumder' ${ }^{1}$ Pawan Govil ${ }^{1}$, Shalini Sharma ${ }^{2}$, Rasik Ravindra ${ }^{3}$, Neloy Khare ${ }^{3}$, Subodh Kumar Chaturvedi ${ }^{4}$ \\ ${ }^{1}$ Birbal Sahni Institute of Palaeobotany, 53 University Road, Lucknow - 226 007, India, e-mail: abhijit.mazumder.email@gmail.com \\ (corresponding author) \\ ${ }^{2}$ Geology Department, Banaras Hindu University, Varanasi - 221 005, U.P., India \\ ${ }^{3}$ Ministry of Earth Sciences, Block 12, CGO Complex, Lodhi Road, New Delhi - 110 003, India \\ ${ }^{4}$ Department of Disaster Management \& CARISM, SASTRA University, Thanjavur - 613 402, Tamil Nadu, India
}

\begin{abstract}
A $47 \mathrm{~cm}$ long sediment core collected from an inland lake of the Vestfold Hills, East Antarctica has been examined to reconstruct the palaeolacustrine environmental changes. The core shows dates at two core intervals of $18-19 \mathrm{~cm}$ and $28-29 \mathrm{~cm}$ as $5050 \pm 98$ yrs BP and 5560 \pm 96 yrs BP, respectively. The core exhibits a good amount of diatom population throughout the length. Prior to $5560 \pm 96 \mathrm{yrs} \mathrm{BP}$, the core shows high abundance of diatom population $\left(>10 \times 10^{7} \mathrm{~g}^{-1}\right)$ along with sufficient salt crystal, which indicates the connection of this lake with the marine environment. From $5560 \pm 96$ yrs BP to $5050 \pm 98$ yrs BP the total number diatoms decreased substantially along with the decrease in salt crystal, which indicates the withdrawal of the marine influence from the lake during that period. From $5050 \pm 98$ yrs BP to Recent, the low number of diatoms and the rare occurrence of salt crystal suggest that the lake remained mostly detached from the sea during the last $5000 \mathrm{yrs}$.
\end{abstract}

Key words: Vestfold Hills, lake sediment core, diatom, salt crystal, connection with sea

\section{Introduction}

Diatoms are one of the few biological components which thrive across a large spectrum of environments, from terrestrial environments, viz. rivers, lakes, wetlands, to coastal lagoons, estuaries, and in near-shore to open ocean environments. Their valves are made of silica, and are preserved in depositional environments and fossilised. For these diatoms become a potential tool for characterising the palaeodepositional environments and hence palaeoclimate. Therefore, diatoms are well used to decipher the palaeoenvironments and palaeoclimates (Stoermer and Smol 1999). Proper interpretation of diatom assemblages depends on their individual ecological inclination. From surface sediment samples the modern diatom distributional pattern and interaction with the environment can be determined. Understanding the distribution and abundance of diatoms in subsurface samples, and their interaction with the past environment, and therefore, the inference drawn to decipher the palaeoclimatic condition are the primary objectives of the present study.

The instrumental record of change in climatic components is unable to show the trend how the climate system operated on time scales in terms of thousands of years (Overpeck 1995). As Antarctica plays a pivotal role in the global climate system, we need to access reliable records of natural climate change patterns from this region, on different time scales, to determine whether present climate changes are natural or a result of anthropogenic forcing. Palaeolimnological records are one of the best sources to determine the natural climatic change in Antarctica. Previously, palaeolimnological records from continental and marine parts of East Antarctica were used several times to address the issue of natural changes in the Antarctic climate (e.g., Vestfold Hills: Roberts and McMinn 1999a,b; Roberts et al. 1999, 2001a; Larsemann Hills: Hodgson et al.2001a; Verleyen et al. 2004; Bunger Hills: Melles et al. 1997; Verkulich et al. 2002; Rauer Islands: Hodgson et al. 2001b; and Maritime and subantarctic islands: 
Jones et al. 2000). The lack of sufficient palaeoclimate data from the Vestfold Hills, East Antarctica needs to be made up for here to bridge the gaps in the palaeoclimatic histories of the major limnological regions of the East Antarctica to establish the continuation of the Holocene climate over the East Antarctic region.

Physical, chemical and biological changes in lakes correspond to climatic changes and these signatures are recorded in lake sediments as different types of proxy (Last and Smol 2001; Battarbee 2000). The water chemistry of an Antarctic lake is substantially related to local climate changes (Roberts et al. 2001). Variations in precipitation and evaporation balance in a catchment area change the concentration or dilution of dissolved salts (Roberts et al. 2001). These changes are registered in different palaeolimnological proxies, including diatom assemblage (Juggins et al. 1994), as diatoms are one of the main biological components of the freshwater benthic algae in Antarctic standing lake waters (Jones 1996). Moreover, diatoms in lake sediments can be utilized to deal with ecological issues and causes for environmental change on varying time scales (Jones 1996). Thus, the diatom from subsurface samples of Antarctic lakes exhibits the local climatic history of the lake basin in any study area.

\section{Study Area}

The Vestfold Hills, Princess Elizabeth Land, form one of a number of rocky, ice-free 'oases' which occur at intervals along the margin of the East Antarctic ice-sheet. Following the retreat of the continental ice-sheet from the region approximately $8000 \mathrm{yrs}$ B.P. (Adamson and Pickard 1986), isostatic rebound led to the gradual emergence of the land from beneath the encroaching ocean. As a result, seawater became trapped in many of the depressions which occur across the Hills (McLeod 1964; Burton 1981). Today, some of these trapped and now highly evaporated water bodies form hypersaline lakes, while flushing out of the relict seawater by glacial meltwaters in other cases has led to the formation of lakes of very low salinity (Pickard et al. 1986).

The Vestfold Hills, covering an area of $410 \mathrm{~km}^{2}$ (Pickard et al. 1986) are situated $157 \mathrm{~m}$ above sea level and on the eastern edge of Prydz Bay on the coast of Princess Elizabeth Land, East Antarctica $\left(68^{\circ} 25^{\prime}\right.$ to $68^{\circ} 40^{\prime} \mathrm{S} ; 77^{\circ} 50^{\prime}$ to $78^{\circ} 35^{\prime} \mathrm{E}$ ). This area is flanked by the East Antarctic Ice Sheet in the east and by the Sørsdal Glacier, an outlet glacier of the ice sheet in the south.
The region is the third largest ice-free region in Antarctica. This region is characterized by long peninsulas, fjords and low hills. This area also truncated by many raised beaches, saline and freshwater lakes.

Prydz Bay is typified by a coastal summer sea surface temperature from -1.1 to $-0.6^{\circ} \mathrm{C}$ (Kerry et al. 1987), but the temperature increases as high as $1.39^{\circ} \mathrm{C}$ near the Vestfold Hills (Gibson 1998). The Vestfold Hills display a polar lowland periglacial climate with a mean annual temperature of $-10.2^{\circ} \mathrm{C}$ (Schwerdtfeger 1970), which is, on average, warmer than Antarctic stations of similar latitude (Burton and Campbell 1980). Although no precipitation data are available, rainfall is very rare, and total precipitation is light $(<250 \mathrm{~mm}$ per year). Melting of snow and ice is restricted to the short summer (December to February). The strong diurnal component of the melt activity usually ceases between $9 \mathrm{pm}$ and $10 \mathrm{am}$, when air temperatures are below or close to $0^{\circ} \mathrm{C}$ and the sun has a low angle of incidence. Because the time of melting is limited, both the rates of ice melt and sediment accumulation are slow. Melt water from ice and snow appears to be the primary control on type and rate of depositional processes.

\section{Materials and Method}

A core with the length of $47 \mathrm{~cm}$ collected from an Antarctic lake (Lat. 68³7’26.7”S; Long. 7758'14.6”E) in the Vestfold Hills area during $24^{\text {th }}$ Indian Antarctic Expedition, was selected for this study (Fig. 1). Core sediments were sub-sampled at intervals of $1 \mathrm{~cm}$.

The methodology for processing the samples and making the diatom slides was followed as described by Setty (1966). The sample was dried overnight at $120^{\circ} \mathrm{C}$. The following day it was treated with $15 \%$ hydrogen peroxide and boiled for 20 minutes in a hot water bath. After boiling, the sample was allowed to stand overnight after adding distilled water. The next day the supernatant liquid was decanted and the residue was boiled with $25 \%$ hydrochloric acid for 15 minutes. After cooling down, the distilled water was added and it was kept overnight. The next day, after decanting the supernatant, $25 \%$ nitric acid was added to the residue and it was kept overnight after adding distilled water. The following day the supernatant was decanted and distilled water was added to the residue, which was kept overnight. Decanting and adding water thereafter were repeated for three consecutive days. On the last day, after decanting the supernatant, the residue was ready to make slides. The residue was 


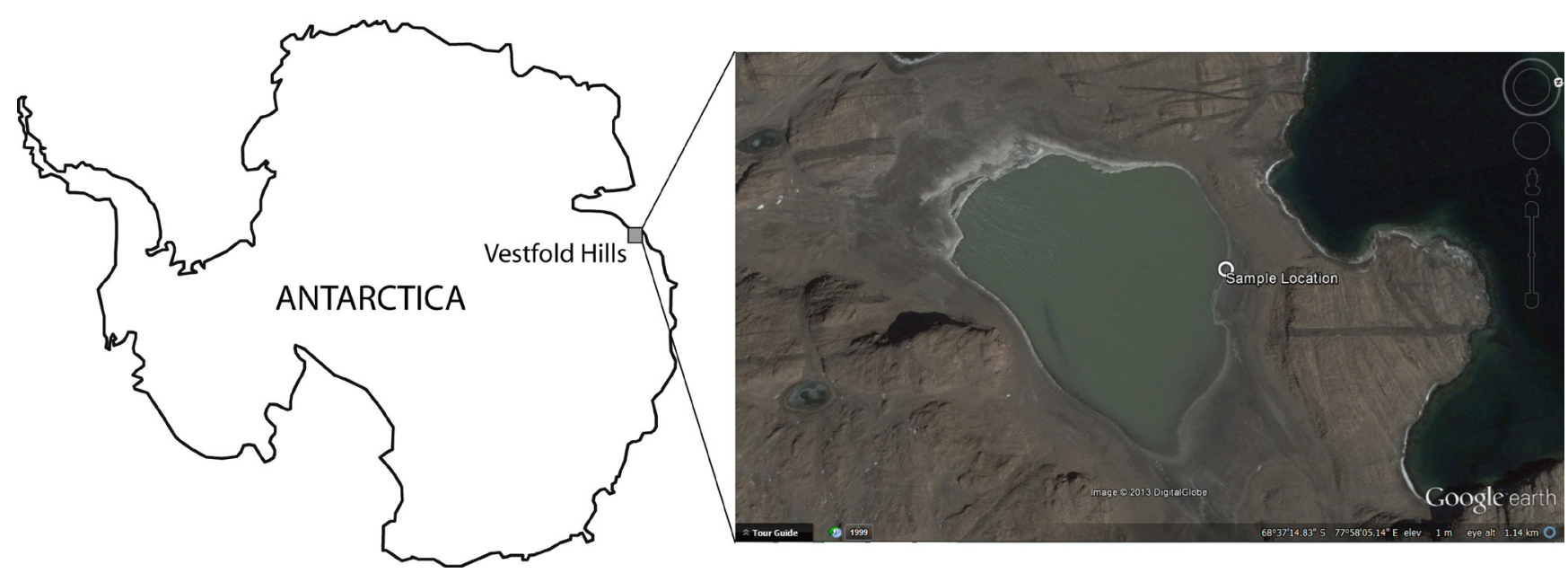

Fig. 1. Location of Lake Sediment Core CD-01

stirred well and the suspension was deposited evenly on the cover glass with the use of a pipette and then the cover glass was allowed to dry. A drop of Canada balsam mounting medium was put on the sample over the cover glass and the cover glass was warmed up to $250^{\circ} \mathrm{C}$, and covered cautiously with a standard glass slide. After cooling the slide was ready for examination under the microscope.

Diatoms were enumerated until a minimum 300 valves had been counted. Estimates of diatom concentration were calculated using the total number of valves counted over a specific area of microscope slide from a known aliquot of sample as follows (modified from Battarbee 1973):

Total valves $=$ valves counted $\times$ area of coverslip / area counted $\times$ sample volume / aliquot volume.

Concentrations are presented as the number of diatom valves per gram of sediment after recalculating with the dry weight of the initial sample used. These provide the relative concentrations between samples in this study.

\section{Results and Discussion}

In the present core, the number of diatoms in 1 gram of dry weight varies with a minimum value of $18 \times 10^{6} \mathrm{~g}^{-1}$ at the core length of $21-22 \mathrm{~cm}$ interval and a maximum value of $13 \times 10^{7} \mathrm{~g}^{-1}$ at $39-40 \mathrm{~cm}$ interval (Fig. 2). The number of diatoms shows a drastic change from $18 \times 10^{6} \mathrm{~g}^{-1}$ to $13 \times 10^{7} \mathrm{~g}^{-1}$ with the intervals of $21-22 \mathrm{~cm}$ and $27-28 \mathrm{~cm}$. Within the core interval $27-40 \mathrm{~cm}$ the total diatom number remains more than $10 \times 10^{7} \mathrm{~g}^{-1}$, while the above and below intervals

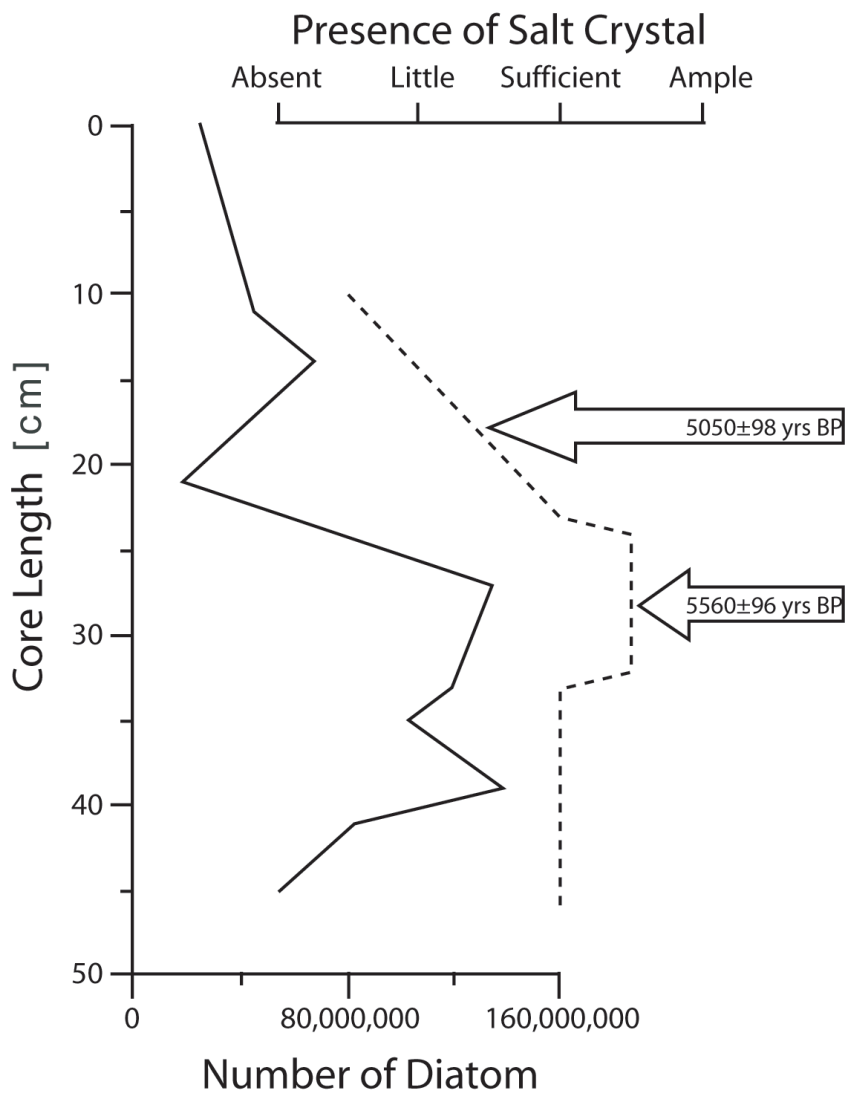

Fig. 2. Plot of total number of diatoms (solid line) and qualitative amount of the presence of salt crystal (dashed line) along the core length 
show a smaller number of diatoms. A total number of 13 species of diatom were identified from the entire core; namely Achnanthes aff. Achnanthes groenlandica, A. taylorensis, Amphora ovalis, Diploneis crabro, D. smithii, Fragilariopsis curta, F. ritscheri, Navicula directa, Navicula sp., Paralia sulcata, Thalassiosira angustelineata and Trachyneis aspera.

As regards the presence of salt, the core interval $0-23 \mathrm{~cm}$ shows the absence or very rare presence of salt crystal. From $23 \mathrm{~cm}$ up to the total core length the presence of sufficient salt crystals is shown in the sample.

Radiocarbon dating of the samples from 18-19 $\mathrm{cm}$ and $28-29 \mathrm{~cm}$ intervals shows the age of the deposition as $5050 \pm 98$ yrs BP and $5560 \pm 96$ yrs BP, respectively. The higher abundance of diatoms $\left(>10 \times 10^{7} \mathrm{~g}^{-1}\right)$ and the presence of sufficient salt crystals within this interval suggest a change in the environmental set up during this period.

Antarctic lakes have long been known to be sensitive recorders of climate change (e.g., Björck et al. 1991; Wasell and Håkansson 1992; Jones et al. 1993; Roberts and McMinn 1998, 1999b). In the absence of instrumental records, these sediments provide wellpreserved proxies for changes in climate on time scales from thousands to tens of years. Climate change affects the physical, chemical and biological changes in a lake environment, which leave their signature on lake sediments (Last and Smol 2001; Battarbee 2000). These changes are recorded in the form of palaeolimnological proxies, including the diatom assemblages (Juggins et al. 1994). Previously it was reported that lesser concentrations of diatoms and their assemblages strongly affected by dissolution were encountered in the Weddell Basin (Zielinski and Gersonde 1997). In spite of changes in the diatom assemblages prior to their incorporation into the sediment record, the biogeographic distribution and the abundance pattern of most of the studied diatom species show a very close relationship with the surface water temperature. These relationships can be used to decipher past surface water temperatures based on statistical analyses of the diatom assemblages or on simple relations of species occurrences in the geological record. Another close link occurs between the distribution of sea ice and sea ice related diatoms (Zielinski and Gersonde 1997). It was accounted that the subarctic North Pacific and marginal seas had much higher values of diatom cells than the subtropical-temperate waters to the south (Marumo 1967; Aizawa et al. 2005). It was found that inshore waters off Vancouver Island have the potential to support larger phytoplankton populations due to higher nutrient values than offshore (Whitney and Freeland 1999). Changes in concentration of diatoms can also be used to record the changes in diatom productivity and hence overall primary productivity (Batterbee 1973, 1978; Bradbury and Waddington 1973; Anderson 1989). Temperature changes, variation in sea ice duration, length of the growing season and light intensity may control the size of the diatom population (Crosta 2009).

In the present study area, the core showing a sudden decrease in diatom population and salt content during $~ 5,000-5,500$ yrs BP indicates the detachment of the lake from marine input around this time. In Ace Lake, the diatom species shows a considerable decrease in number during 5,500 to 3,800 yrs BP time span (Fulford-Smith and Sikes 1996). Bird et al. (1991) established the palaeomarine connection of three lakes, namely Highway Lake, Organic Lake and Ace Lake. According to them, the detachment of these now inland lakes from the sea happened within 2700 and 5400 yrs B.P. (for Highway Lake it was 4600 yrs B.P., for Organic Lake it was 2700 yrs B.P. and for Ace Lake it was 5400 yrs B.P.).

The early and early-mid-Holocene $(\sim 10,500$ to $\sim 4000$ yrs BP) is characterized by the Antarctic glacial retreat (Goodwin 1998). In the southern Windmill Islands and Vestfold Hills, the early and early-mid-Holocene show a stage of glacial retreat with relatively cool temperatures and low bioproductivity (Cremer et al. 2003; Cromer et al. 2005). With the decrease in the marine influence, minimization of faunal assemblages occurred as biota depending on the immigration of larval stages into the basin could no longer continue their populations. A similar type of decrease in biodiversity has been reported from marine lakes formed by isostatic uplift in recent times (Ström and Klaveness 2003), and other seasonally isolated marine basins in the Vestfold Hills (Bayly 1986; Eslake et al. 1991). The lake from the present study area shows the detachment of the lake from marine influence, which is probably linked with the glacial retreat in this area during 5,000-5,500 yrs BP.

\section{Conclusion}

The presence of abundant diatoms $\left(>10 \times 10^{7}\right.$ $\left.\mathrm{g}^{-1}\right)$ along with sufficient salt crystal at the bottom of the core suggests the connection of the lake with the 
sea before 5,500 yrs BP. During 5,500 to 5,000 yrs BP, the decrease in salt crystal and diatom population indicates the detachment of the lake from a marine connection at that time. Afterwards the lake continued its status of being disconnected from continuous marine connection.

\section{Acknowledgements}

The authors would like to express their thanks to Director, National Centre for Antarctic and Ocean Research, Goa, India and Director, Birbal Sahni Institute of Palaeobotany, Lucknow, India.

\section{References}

Adamson D.A., Pickard J., 1986, Cainozoic history of the Vestfold Hills, [in:] Pickard, J. (ed), Antarctic Oasis, Academic Press, Sydney: 63-97.

Aizawa C., Tanimoto M., Jordan R.W., 2005, Living diatom assemblages from North Pacific and Bering Sea surface waters during summer 1999, Deep-Sea Res. II 52: 21862205.

Anderson N.J., 1989, A whole-basin diatom accumulation rate for a small eutrophic lake in Northern Ireland and its paleoecological implications, J. Ecol. 75: 926-946.

Battarbee R.W., 1973, A new method for the estimation of absolute microfossil numbers with reference especially to diatoms, Limnol. Oceanogr. 18: 647-653.

Batterbee R.W., 1978, Observations on the recent history of Lough Neagh and its drainage basin, Phil. Trans. Royal Soc. 281: 303-345.

Battarbee R.W., 2000, Palaeolimnological approaches to climate change, with special regard to the biological record, Quat. Sci. Rev. 19: 107-124.

Bayly I.A.E., 1986, Ecology of the zooplankton of a meromictic Antarctic lagoon with special reference to Drepanopus bispinosus (Copepoda: Calanoida), Hydrobiologia 140: 199-231.

Bird M.I., Chivas A.R., Radnell C.J., Burton H.R., 1991, Sedimentological and stable-isotope evolution of lakes in the Vestfold Hills, Antarctica, Palaeogeogr. Palaeoclimatol. Palaeoecol. 84: 109-130.

Björck S., Håkansson H., Zale R., Karlén W., Jönsson B.L., 1991, A late Holocene lake sediment sequence from Livingston Island, south Shetland Islands, with palaeoclimatic implications, Ant. Sci. 3: 61-72.

Bradbury J.P., Waddington J.C.B., 1973, The impact of European settlement on Shagawa Lake, Northeastern Minnesota, U.S.A., [in:] Birks J.B.H., West R.G. (eds), Quaternary Plant Ecology, Blackwell Scientific Publications, Oxford: 289-307.

Burton H.R., 1981, Chemistry, physics and evolution of Antarctic saline lakes: a review, Hydrobiologia 82: 339-362.
Burton H.R., Campbell P.J., 1980, The climate of the Vestfold Hills, Davis Station, Antarctica, with a note on its effect on the hydrology of hypersaline Deep Lake, WARE Scientific Reports, Series D 129: 1-50.

Cremer H., Gore D., Melles M., Roberts D., 2003, Palaeoclimatic significance of late Quaternary diatom assemblages from southern Windmill Islands, East Antarctica, Palaeogeogr. Palaeoclimatol. Palaeoecol. 195: 261-280.

Cromer L., Gibson J.A.E., Swadling K.M., Ritz D.A., 2005, Faunal microfossils: Indicators of Holocene ecological change in a saline Antarctic lake, Palaeogeogr. Palaeoclimatol. Palaeoecol. 221: 83-97.

Crosta X., 2009, Holocene size variations in two diatom species off East Antarctica: productivity vs environemtal conditions, Deep-Sea Res. I 56: 1983-1993.

Eslake D., Kirkwood R., Burton H., Zipan W., 1991, Temporal changes in zooplankton composition in a hypersaline, Antarctic lake subject to periodic seawater incursions, Hydrobiologia 210: 93-99.

Fulford-Smith S.P., Sikes E.L., 1996, The evolution of Ace Lake, Antarctica, determined from sedimentary diatom assemblages, Palaeogeogr. Palaeoclimatol. Palaeoecol. 124: 73-86.

Gibson J.A., 1998, Carbon flow through inshore marine environments of the Vestfold Hills, East Antarctica, ANARE Reports 139, Australian Antarctic Division, Kingston, p. 222.

Goodwin I.D., 1998, Did changes in Antarctic ice volume influence late Holocene sea-level lowering?, Quat. Sci. Rev. 17: 319-332.

Hodgson D., Noon P., Vyverman W., Bryant C., Gore D., Appleby P., Gilmour M., Verleyen E., Sabbe K., Jones V., Ellis-Evans J., Wood P., 2001a, Were the Larsemann Hills ice free through the Last Glacial Maximum?, Ant. Sci. 13: 440-454.

Hodgson D., Vyverman W., Sabbe K., 2001b, Limnology and biology of saline lakes in the Rauer Islands, Eastern Antarctica, Ant. Sci. 13: 255-270.

Jones V.J., 1996, The diversity, distribution and ecology of diatoms from Antarctic inland waters, Biodiv. Conserv. 511: 1433-1449.

Jones V., Hodgson D., Chepstow-Lusty A., 2000, Palaeolimnological evidence for marked Holocene environmental changes on Signy Island, Antarctica, Holocene 10: 43-60.

Jones V.J., Juggins S., Ellis-Evans J.C., 1993, The relationship between chemistry and surface sediment diatom assemblages in maritime Antarctic lakes, Ant. Sci. 5: 339-348.

Juggins S., Battarbee R.W., Fritz S.C., Gasse F., 1994, The CASPIA project: diatoms, salt lakes, and environmental change, J. Paleolimnol. 12: 191-196.

Kerry K.R., Woehler E.J., Wright S., Dong Z., 1987, Oceanographic data : Prydz Bay region : FIBEX, MV Dan, Janurary-March 1981, ANARE Research Notes 49, Australian Antarctic Division, Kingston, p. 114.

Last W.M., Smol J.P., 2001, Tracking Environmental Change Using Lake Sediments, Kluwer Academic Publishing, Dordrecht, p. 548. 
Marumo R., 1967, General features of diatom communities in the North Pacific Ocean in summer, Inform. Bull. Planktol. Jap. 12: 115-121.

McLeod I.R., 1964, The saline lakes of the Vestfold Hills, Princess Elizabeth Land, [in:] Adie R.J. (ed), Antarctic Geology, North-Holland, Amsterdam: 65-72.

Melles M., Kulbe T., Verkulich S., Pushina Z., Hubberten H.W., 1997, Late Pleistocene and Holocene environmental history of Bunger Hills, East Antarctica, as revealed by fresh-water and epishelf lake sediments, [in:] Ricci C.A. (ed), The Antarctic Region: Geological Evolution and Processes, Terra Antarctica Publication, Siena: 809-820.

Overpeck J.T., 1995, Paleoclimatology and climate system dynamics. U.S. National Report to IUGG, 1991-1994, Reviews in Geophysics, American Geophysical Union, Washington D.C., U.S.A. 33: 1-17.

Pickard J., Adamson D.A., Heath C.W., 1986, The evolution of Watts Lake, Vestfold Hills, East Antarctica, from marine inlet to freshwater lake, Palaeogeogr. Palaeoclimatol. Palaeoecol. 53: 271-288.

Roberts D., McMinn A., 1998, A weighted-averaging regression and calibration model for inferring lakewater salinity from fossil diatom assemblages in saline lakes of the Vestfold Hills: implications for interpreting Holocene lake histories in Antarctica, J. Paleolimnol. 19: 99-113.

Roberts D., McMinn A., 1999a, Diatoms of the saline lakes of the Vestfold Hills, Antarctica, Bibliotheca Diatomologica 44: 1-83.

Roberts D., McMinn A., 1999b, A diatom-based palaeosalinity history of Ace Lake, Vestfold Hills, Antarctica, Holocene 9: 401-408.

Roberts D., Roberts J.L., Gibson J.A.E., McMinn A., Heijnis H., 1999, Palaeohydrological modelling of Ace Lake, Vestfold Hills, Antartica, Holocene 9: 515-520.
Roberts D., van Ommen T.D., McMinn A., Morgan V., Roberts J.L., 2001, Late Holocene climate trends from East Antarctic ice core and lacustrine sediment core records, Holocene 11: 117-120.

Schwexdtfeger W., 1970, The climate of Antarctica, [in:] Orvig S. (ed), Climates of Polar Regions, Elsevier, Amsterdam: 253-355.

Setty M.G.A.P., 1966, Preparation and method of study of fossil diatoms, Micropaleontol. 12: 511-514.

Stoermer E.F., Smol J.P., 1999, The Diatoms: Applications for the Environmental and Earth Sciences. Cambridge University Press, Cambridge, p. 469.

Ström T.-E., Klaveness D., 2003, Hunnebotn: a seawater basin transformed by natural and anthropogenic processes, Est. Coast. Shelf Sci. 56: 1177-1185.

Verkulich S., Melles M., Pushina Z., Hubberten H.-W., 2002, Holocene environmental changes and evolution of Figurnoye Lake in the southern Bunger Hills, East Antarctica, J. Paleolimnol. 28: 253-267.

Verleyen E., Hodgson D., Sabbe K., Vyverman W., 2004, Late Quaternary deglaciation and climate history of the Larsemann Hills (East Antarctica), J. Quat. Sci. 19: 361375.

Wasell A., Håkansson H., 1992, Diatom stratigraphy in a lake on Horseshoe Island, Antarctica: a marine-brackish-freshwater transition with comments on the systematics and ecology of the most common diatoms, Diatom Res. 7: 157-194.

Whitney F.A., Freeland H.J., 1999, Variability in upperocean water properties in the NE Pacific Ocean, DeepSea Res. II 46: 2351-2370.

Zielinski U., Gersonde R., 1997, Diatom distribution in Southern Ocean surface sediments (Atlantic sector): Implications for paleoenvironmental reconstructions, Palaeogeogr. Palaeoclimatol. Palaeoecol. 129: 213-250. 